\title{
IGFBP2 Gene
}

National Cancer Institute

\section{Source}

National Cancer Institute. IGFBP2 Gene. NCI Thesaurus. Code C28589.

This gene plays a role in insulin-like growth factor modulation and intercellular communication. 